FIU Law Review

Still "Snowing" in the Sunshine State: An Analysis of and Potential Solutions to the Lack of Protection from Employer Retaliation for Florida Lawyers Who Adhere to the State's Mandatory Reporting of Professional Misconduct Rule

Jason A. Anon

J.D. candidate, 2019, Florida International University (FIU) College of Law, janon004@fiu.edu

Follow this and additional works at: https://ecollections.law.fiu.edu/lawreview

Part of the Contracts Commons, Labor and Employment Law Commons, Legal Ethics and

Professional Responsibility Commons, State and Local Government Law Commons, and the Torts

Commons

Online ISSN: 2643-7759

Recommended Citation

Jason A. Anon, Still "Snowing" in the Sunshine State: An Analysis of and Potential Solutions to the Lack of Protection from Employer Retaliation for Florida Lawyers Who Adhere to the State's Mandatory Reporting of Professional Misconduct Rule, 13 FIU L. Rev. 1175 (2019).

DOI: https://dx.doi.org/10.25148/lawrev.13.6.15

This Comment is brought to you for free and open access by eCollections. It has been accepted for inclusion in FIU Law Review by an authorized editor of eCollections. For more information, please contact lisdavis@fiu.edu. 


\title{
STILL "SNOWING" In THE SunShine State: An ANAlysis of ANd Potential Solutions to THE LACK OF PROTECTION FROM EMPLOYER RETALIATION FOR FLORIDA LAWYERS WHO ADHERE TO THE STATE'S MANDATORY REPORTING OF PROFESSIONAL MisCONDUCT RULE
}

\author{
Jason A. Anon*
}

\begin{abstract}
The Preamble to the Florida Rules of Professional Conduct establishes lawyers as "officers of the court" and recognizes the self-governing nature of the legal profession. As such, in addition to requiring adherence to the rules, the Florida Rules of Professional Conduct also endow all lawyers with the responsibility of ensuring other lawyers' adherence to the rules. This charge of responsibility is directly stated in Section 4-8, Maintaining the Integrity of the Profession. More specifically, subsection (a) of Rule 4-8.3, Reporting Professional Misconduct, explicitly requires "[a] lawyer who knows that another lawyer has committed a violation of the Rules of Professional Conduct that raises a substantial question as to that lawyer's honesty, trustworthiness, or fitness as a lawyer in other respects [to] inform the appropriate professional authority."

Although Rule 4-8.3(a) requires lawyers to report such misconduct, the Rules fail to provide any express protection for lawyers who are retaliated against by employers because they report (or insist on reporting) the misconduct of other lawyers. Furthermore, Florida courts do not recognize the common law tort cause of action for retaliatory or wrongful discharge; the Second District Court of Appeal of Florida has also held that Florida lawyers are precluded from redress under Florida's Private Sector Whistleblower Act when they are retaliated against by an employer for adhering to (or insisting on adherence to) Florida's mandatory reporting requirement; and Florida courts will not find a breach of the contractual implied covenant of good faith and fair dealing (unless an express term of the

\footnotetext{
* J.D. candidate, 2019, Florida International University (FIU) College of Law. Special thanks to Professor Rosario Lozada Schrier, Associate Professor of Legal Skills and Values, for inspiring this Comment and for her unceasing dedication and guidance throughout the drafting process. Many thanks to the Editorial Board and Staff of the FIU Law Review for their unrelenting efforts in seeing this Comment through to final publication. To Mom, Dad, Mike, Ale, and the rest of my family and friends for your unparalleled support and encouragement. And to Gabrielle Aurora for always believing in me, brightening my darkest days, and filling my life with inspiration, meaning, and purpose.
} 
at-will employment contract has been breached) in situations where at-will lawyers are similarly retaliated against.

Thus, given the tension between the mandatory reporting requirement of Rule 4-8.3(a) and the lack of protection from employer retaliation for lawyers who report or insist on reporting the misconduct of other lawyers, (1) Florida courts should recognize in such situations a tort cause of action for retaliatory or wrongful discharge in contravention of public policy, (2) the Florida Legislature should redraft the Definitions section of the Florida Private Sector Whistleblower Act to include the Florida Rules of Professional Conduct into the definition of "[1]aw, rule, or regulation," (3) Florida courts should allow claims for breach of the implied covenant of good faith and fair dealing with respect to at-will lawyers' employment contracts in such situations, or (4) the Florida Supreme Court should draft a new rule (or alternatively include as a provision or comment under Rule 4-8.4, Misconduct) in the Florida Rules of Professional Conduct proscribing such employer retaliation.

I. Introduction 1176

II. Background

A. The Duty to Report Professional Misconduct in Florida:

Rule 4-8.3(a).

B. The Significance of Reporting Professional Misconduct...... 1182

C. Florida Retaliatory or Wrongful Discharge Law 1185

D. Florida At-Will Employment Contract Law and the Implied Covenant of Good Faith and Fair Dealing

III. A Lack of Protection from Employer Retaliation. 1188

IV. Potential Solutions to the Lack of Protection from Employer Retaliation

A. Other Jurisdictions' Judicial Solutions 1193

B. Analysis of Judicial Solutions and Discussion of Other Nonjudicial Solutions

V. Conclusion 1205

\section{INTRODUCTION}

After completing three long years of law school and passing the Florida Bar Examination, you are finally hired as an associate at a private law firm, a position that you have been searching for tirelessly since becoming a licensed attorney in the State of Florida. While it has surely taken some time and effort to adjust from law school to law firm life, you find yourself settling in with your workload and becoming familiar with your firm's culture and 
operations. ${ }^{1}$ However, after several months of work, you begin to realize that occasionally some of the firm's practices (as well as the conduct of some of the other lawyers) are not always as entirely forthright as they should be. For example, some of the improprieties you might observe are that the work of junior associates - including your own-is occasionally inadequately supervised; clients are sometimes provided altered copies of documents that were supposedly filed as-is with the court; firm performance evaluations and client billing statements are sometimes partially fabricated; and one of your supervisors has falsely represented to the firm on a few occasions that he prepared a document when he had actually never even read it. ${ }^{2}$

As you make these observations, you remember sitting in your law school professional responsibility courses or professional ethics seminars and learning about the high standards to which lawyers are held because of their positions of trust within the community and their "special responsibility for the quality of justice." 3 You also know that as members of the Florida Bar, you and your colleagues are held to heightened professional standards, including the mandatory duty to report serious professional misconduct that reflects on a lawyer's fitness to practice law. ${ }^{4}$ At the same time, however, you mentally juggle your professional duties and obligations against other considerations, such as being labeled as a "snitch" or "rat" within the firm, being ostracized by your supervisors and coworkers, earning the reputation of a "troublemaker" within the legal community (and suffering the associated employment consequences as a result, for example), and even facing employer retaliation such as demotion or termination for reporting or insisting on reporting this professional misconduct consistent with your professional responsibilities. ${ }^{5}$

While you consider simply "looking the other way" after contemplating the potential consequences or effects that could result from a disturbance of

1 See Douglas R. Richmond, Professional Responsibilities of Law Firm Associates, 45 BRANDEIS L.J. 199, 201 (2007).

2 These facts loosely represent the situation in Wallace v. Skadden, Arps, Slate, Meagher, \& Floam, 715 A.2d 873, 883 (D.C. Cir. 1998).

3 Fla. Rules of Prof'L CONDUCT pmbl. (The Fla. BAR 2012) (“As a public citizen, a lawyer should seek improvement of the law, access to the legal system, the administration of justice, and the quality of service rendered by the legal profession. As a member of a learned profession, a lawyer should cultivate knowledge of the law beyond its use for clients, employ that knowledge in reform of the law, and work to strengthen legal education. In addition, a lawyer should further the public's understanding of and confidence in the rule of law and the justice system, because legal institutions in a constitutional democracy depend on popular participation and support to maintain their authority.").

4 See id. at r. 4-8.3(a).

5 Douglas R. Richmond, Associates as Snitches and Rats, 43 WAYNE L. REV. 1819, 1821 (1997); see also Terri Martin Kirik, Retaliatory Discharge for Attorney-Employees in Private Practice: To Do, or Not To Do, the "Right Thing”, 33 J. MARShaLl L. REV. 383, 383-84 (2000). 
your firm's current equilibrium, ${ }^{6}$ you ultimately decide to report the professional misconduct you have observed to your supervising attorney. First, you understand the foundational importance behind your duty to report such misconduct. ${ }^{7}$ Second, you want to avoid being complicit and included as part of the misconduct or otherwise subjected to disciplinary action. And third, you think that even if your employing law firm did terminate or otherwise retaliate against you, you would surely be protected by some sort of remedy given that, after all, you were simply following a mandatory obligation to report under the Florida Rules of Professional Conduct. ${ }^{8}$ But think again.

The Florida Rules of Professional Conduct entrust all lawyers licensed to practice in the State of Florida with the responsibility of maintaining the integrity of the legal profession by not only adhering to the rules themselves, but also by ensuring other lawyers' adherence to the rules: "A lawyer who knows that another lawyer has committed a violation of the Rules of Professional Conduct that raises a substantial question as to that lawyer's honesty, trustworthiness, or fitness as a lawyer in other respects shall inform the appropriate professional authority." "While "[r]eporting on a member of your own profession is usually an unpleasant act, ${ }^{10} \ldots$ it is necessary for the protection of the public because co-professionals are often the only people who become aware of misconduct." 11 As a parallel, concrete example, most people would likely want the doctors in an operating room to report a fellow

6 See Balla v. Gambro, Inc., 584 N.E.2d 104, 113 (Ill. 1998) (Freeman, J., dissenting) (“[A]s unfortunate for society as it may be, attorneys are no less human than nonattorneys and, thus, no less given to the temptation to either ignore or rationalize away their ethical obligations when complying therewith may render them unable to feed and support their families.").

7 See Wieder v. Skala, 609 N.E.2d 105, 109 (N.Y. 1992) ("The reporting requirement is nothing less than essential to the survival of the [legal] profession.") (internal citations omitted).

8 See Fla. Rules of Prof'L CONDuCt r. 4-8.3(a) (The Fla. BAR 2012).

9 Id.; see also id. at pmbl. ("[E]very lawyer is responsible for observance of the Rules of Professional Conduct. A lawyer should also aid in securing their observance by other lawyers. Neglect of these responsibilities compromises the independence of the profession and the public interest that it serves.").

10 Lawyers are reluctant to report their peers because of widespread ambivalence about or negative attitudes toward self-reporting, ignorance, and fear of retaliation. The rate of reporting for lawyers working in the same firm is lower still for at least two reasons. First, lawyers feel greater loyalty to their colleagues. Second, because co-workers often have exclusive knowledge of another lawyer's misconduct, they more acutely fear discovery and retaliation.

Richmond, supra note 5, at 1838

11 Lisa G. Lerman \& Philip G. Schrag, Ethical Problems in the PraCtice of Law 92 (4th ed. 2016); see also Sandra J. Mullings, Wieder v. Skala: A Chink in the Armor of the At-Will Doctrine or a Lance for Law Firm Associates?, 45 SYRACUSE L. REV. 963, 994 (1995) ("[P]rofessional peers are in the best position to detect misconduct and, therefore, to serve the public interest of identifying and removing incompetent or unethical practitioners."). 
doctor or surgeon to authorities if they knew he was intoxicated during an operation. ${ }^{12}$

But the Florida Rules of Professional Conduct are silent on the issue of protections for lawyers who are retaliated against by their employing law firms for reporting or insisting on reporting the misconduct of other lawyers. Additionally, Florida courts do not recognize the common law tort cause of action for retaliatory or wrongful discharge, ${ }^{13}$ the Second District Court of Appeal of Florida has also held that Florida lawyers are precluded from redress under Florida's Private Sector Whistleblower $\mathrm{Act}^{14}$ when they are retaliated against by an employer for adhering to (or insisting on adherence to) Florida's mandatory reporting requirement; ${ }^{15}$ and Florida courts will not find a breach of the contractual implied covenant of good faith and fair dealing (unless an express term of the at-will employment contract has been breached) in situations where at-will lawyers are similarly retaliated against. $^{16}$

Thus, given the tension between the mandatory reporting requirement of Rule 4-8.3(a) and the lack of protection from employer retaliation for lawyers who report or insist on reporting the misconduct of other lawyers, (1) Florida courts should recognize in such situations a tort cause of action for retaliatory or wrongful discharge in contravention of public policy, (2) the Florida Legislature should redraft the Definitions section of the Florida Private Sector Whistleblower Act to include the Florida Rules of Professional Conduct into the definition of "[1]aw, rule, or regulation," (3) Florida courts should allow claims for breach of the implied covenant of good faith and fair

12 LERMAN \& SCHRAG, supra note 11.

13 See Smith v. Piezo Tech. and Prof'l Adm'rs, 427 So. 2d 182, 184 (Fla. 1983); DeMarco v. Publix Super Mkts., Inc., 384 So. 2d 1253, 1254 (Fla. 1980) (affirming and adopting reasoning of DeMarco v. Publix Super Mkts., 360 So. 2d 134, 136 (Fla. Dist. Ct. App. 1978)); Hartley v. Ocean Reef Club, Inc., 476 So. 2d 1327, 1330 (Fla. Dist. Ct. App. 1985).

14 Fla. Stat. $\S$ 448.101-.105 (2017).

15 Snow v. Ruden, McClosky, Smith, Schuster \& Russell, P.A., 896 So. 2 d 787 (Fla. Dist. Ct. App. 2005). Although this case represents a decision from a mid-level Florida District Court of Appeal, its dictates are entirely significant because the Florida Supreme Court has acknowledged that Florida district courts' decisions "represent the law of Florida unless and until they are overruled" by it. Pardo v. State, 596 So. 2d 665, 666 (Fla. 1992) (quoting Stanfill v. State, 384 So. 2d 141, 143 (Fla. 1980)). "[I]n the absence of interdistrict conflict, district court decisions bind all Florida trial courts." Pardo, 596 So. 2 d at 666 (citing Weiman v. McHaffie, 470 So. 2d 682, 684 (Fla. 1985)). Furthermore,

in the event the only case on point on a district level is from a district other than the one in which the trial court is located, the trial court [is] required to follow that decision. . . Contrarily, as between District Courts of Appeal, a sister district's opinion is merely persuasive. Id. at 666-67 (quoting State v. Hayes, 333 So. 2d 51, 53 (Fla. Dist. Ct. App. 1976)).

16 See Snow, 896 So. 2d at 791-92; Ins. Concepts and Design, Inc. v. Healthplan Servs., Inc., 785 So. 2d 1232, 1234 (Fla. Dist. Ct. App. 2001); Burger King Corp. v. Weaver, 169 F.3d 1310, 1316 (11th Cir. 1999); Hospital Corp. of America v. Fla. Med. Ctr., Inc., 710 So. 2d 573, 575 (Fla. Dist. Ct. App. 1998). 
dealing with respect to at-will lawyers' employment contracts in such situations, or (4) the Florida Supreme Court should draft a new rule (or alternatively, include as a provision or comment under Rule 4-8.4, Misconduct) in the Florida Rules of Professional Conduct proscribing such employer retaliation. By applying these potential solutions to the ironic paradox existing between a mandatory reporting of professional misconduct rule and a lack of attorney protection from employer retaliation for lawyers adhering to the reporting rule, Florida lawyers will no longer be "left out in the cold" by Snow v. Ruden, McClosky et al., Florida's at-will employment doctrine, or the silence of the Rules themselves.

Part II of this Comment provides the background and framework underlying the tension between the mandatory reporting requirement and the lack of protection against employer retaliation for lawyers. This section analyzes Rule 4-8.3(a) of the Florida Rules of Professional Conduct, discusses the importance of adhering to the mandatory reporting requirement, and surveys Florida retaliatory or wrongful discharge law (including an analysis of the Florida Private Sector Whistleblower Act) and Florida at-will employment contract law. Part III examines the Florida District Court of Appeal case currently dictating Florida's position on this issue, as well as analyzes case examples from other jurisdictions that have adopted positions similar to Florida's. On the other hand, Part IV presents case examples from jurisdictions that have responded more favorably to the issue for reporting lawyers; and these cases offer guidelines for potential solutions to the predicament in Florida. Additionally, this section addresses the possibility of a legislative solution to the issue as well as a partial solution involving the Florida Rules of Professional Conduct themselves. Last, Part V summarizes where Florida currently stands and where it should be heading.

\section{BACKGROUND}

\section{A. The Duty to Report Professional Misconduct in Florida: Rule 4-8.3(a)}

Rule 4-8.3(a) of the Florida Rules of Professional Conduct consists of three parts: a knowledge requirement, a gauge of the severity of the professional misconduct that must be reported, and a mandatory reporting obligation. First, the language of Rule 4-8.3(a) is couched in terms of a lawyer's knowledge of another lawyer's violation of the Rules of Professional Conduct. ${ }^{17}$ "The standard for assessing knowledge is objective. The knowledge must be more than a mere suspicion that misconduct has occurred.

17 See Fla. Rules of Prof'L Conduct r. 4-8.3(a) (The Fla. Bar 2012). 
The question is whether 'a reasonable lawyer in the circumstances would have a firm opinion that the conduct in question more likely than not occurred." $" 18$

Next, the mandatory reporting requirement under Rule 4-8.3(a) is qualified by the language "raises a substantial question as to that lawyer's honesty, trustworthiness, or fitness as a lawyer in other respects." $" 19$ The major implication of this language, which is also the source of considerable confusion and significant "gray area," is that not all violations of the Florida Rules of Professional Conduct trigger Rule 4-8.3(a)'s mandatory reporting requirement. ${ }^{20}$ As the comment to the rule indicates, the "reporting obligation [is limited] to those offenses that a self-regulating profession must vigorously endeavor to prevent.... The term 'substantial' refers to the seriousness of the possible offense and not the quantum of evidence of which the lawyer is aware." ${ }^{21}$ Accordingly, where a lawyer observes professional or ethical misconduct, such as noticing a colleague neglecting work because of substance abuse, encountering an opposing counsel who intentionally obstructs discovery, or being asked to falsify time records by a supervisor, ${ }^{22}$ the qualification in Rule 4-8.3(a) requires the lawyer to examine whether reporting the other lawyer's misconduct is obligated because its severity or relation to the practice of law "raises a substantial question as to that lawyer's honesty, trustworthiness, or fitness as a lawyer in other respects." 23

Furthermore, in terms of determining whether the severity of a particular instance of professional misconduct has triggered an attorney's mandatory reporting obligation, Rule 4-8.4, Misconduct, and its comment provide additional guidance into this inquiry; the Rule explicitly proscribes specific actions and conduct that are per se misconduct (based on their inclusion in the rule proscribing misconduct) and would thus trigger the reporting requirement. ${ }^{24}$ The Rule's comment also provides the following explanation:

Many kinds of illegal conduct reflect adversely on fitness to practice law, such as offenses involving fraud and the

18 See LERMAN \& Schrag, supra note 11 at 91 (quoting Restatement $\S 5 \mathrm{cmt}$. i).

19 Fla. Rules of PROF'L CONDUCT r. 4-8.3(a) (THE Fla. BAR 2012) (emphasis added).

$20 I d$. at r. 4-8.3 cmt. 3 ("If a lawyer were obliged to report every violation of the rules, the failure to report any violation would itself be a professional offense. Such a requirement existed in many jurisdictions, but proved to be unenforceable.").

21 Id. at cmt. 2 (Along these lines, "[a] report about misconduct is [also] not required where it would involve violation of rule 4-1.6 [(Confidentiality of Information)]. However, a lawyer should encourage a client to consent to disclosure where prosecution would not substantially prejudice the client's interests.").

22 LERMAN \& SCHRAG, supra note 11 at 91.

23 Fla. Rules of Prof’L CONDUCT r. 4-8.3(a) (The Fla. BAR 2012) (emphasis added).

24 See id. at r. 4-8.4. The Rule begins with the broad proscription, "[a] lawyer shall not:" before proceeding to enumerate various actions and conduct (a)-(i) explicitly deemed misconduct under the Rule. 
offense of willful failure to file an income tax return. However, some kinds of offense carry no such implication. Traditionally, the distinction was drawn in terms of offenses involving "moral turpitude." That concept can be construed to include offenses concerning some matters of personal morality, such as adultery and comparable offenses, that have no specific connection to fitness for the practice of law. Although a lawyer is personally answerable to the entire criminal law, a lawyer should be professionally answerable only for offenses that indicate lack of those characteristics relevant to law practice. Offenses involving violence, dishonesty, or breach of trust or serious interference with the administration of justice are in that category. ${ }^{25}$

Lastly, the word "shall" in Rule 4-8.3(a) is significant because it makes the professional reporting requirement mandatory. ${ }^{26}$ As opposed to many other rules and comments in the Florida Rules of Professional Conduct, which merely recommend courses of action or provide guidelines, ${ }^{27}$ Rule 48.3(a) makes it such that a lawyer with knowledge of another lawyer's "violation of the Rules of Professional Conduct that raises a substantial question as to that lawyer's honesty, trustworthiness, or fitness as a lawyer in other respects" must report it to the "appropriate professional authority." 28

\section{B. The Significance of Reporting Professional Misconduct}

While Florida and the vast majority of states have adopted mandatory reporting rules, relatively few public disciplinary reports have been issued in which lawyers are disciplined for failing to adhere to their reporting obligations. ${ }^{29}$ Scholars recognize, however, that lawyers in several states have indeed been sanctioned in various instances for failing to report, although formal opinions on the matters were never published. ${ }^{30}$ In any regard, state courts maintain the importance of self-regulation of the legal profession and take seriously attorneys' failures to report misconduct under

$25 I d$. at cmt. 1 (Furthermore, "[a] pattern of repeated offenses, even ones of minor significance when considered separately, can indicate indifference to legal obligation.").

26 Id. at r. 4-8.3(a).

27 See id. at pmbl. ('Some of the rules are imperatives, cast in the terms of 'must,' 'must not,' or 'may not.' These define proper conduct for purposes of professional discipline. Others, generally cast in the term 'may,' are permissive and define areas under the rules in which the lawyer has discretion to exercise professional judgment.").

28 Id. at r. 4-8.3(a)

29 See LeRMAN \& Schrag, supra note 11 at 91.

30 Id. at 94 n.91. 
mandatory reporting rules of professional conduct as exemplified in a groundbreaking case, In re Himmel. ${ }^{31}$

In In re Himmel, Tammy Forsberg retained Attorney Casey to represent her in a personal injury/property damage case resulting from a motorcycle accident. ${ }^{32}$ A $\$ 35,000$ settlement was negotiated, and pursuant to his agreement with Forsberg, Casey was entitled to one-third of any money received as his attorney fee. ${ }^{33}$ Nonetheless, Casey ended up converting the funds received, and Forsberg retained Attorney Himmel to collect her money, agreeing to pay Himmel one-third of any money recovered..$^{34}$ Accordingly, Himmel then drafted an agreement in which Casey agreed to pay Forsberg $\$ 75,000$ in exchange for Forsberg's agreement to not initiate any criminal, civil, or disciplinary actions against Casey. ${ }^{35}$ When Casey subsequently failed to pay, however, Himmel then filed suit against Casey and obtained a $\$ 100,000$ judgment was entered against Casey. ${ }^{36}$

The issue before the Supreme Court of Illinois was that Himmel had "received unprivileged information that Casey converted Forsberg's funds, and that [Himmel] failed to relate the information to the Commission in violation of Rule 1 -- 103(a) of the Code. ${ }^{37}$ Recognizing the emphasis of the "importance of a lawyer's duty to report misconduct," the court found that the information Himmel possessed regarding Casey's conduct was not protected by the attorney-client privilege and so was not exempt from the reporting rule. ${ }^{38}$ This was because (1) Forsberg did not communicate the information to Himmel in confidence because she voluntarily discussed the matter with Himmel in the presence of third parties such as her mother and fiancé, and (2) the information was intended to be disclosed by Himmel (with Forsberg's consent) to third parties such as the insurance company involved, the insurance company's lawyer, and Casey himself. ${ }^{39}$ As such, the court concluded that Himmel "possessed unprivileged knowledge of Casey's conversion of client funds, which [was] illegal conduct involving moral

31 See id. at 93

32 In re Himmel, 533 N.E.2d 790, 791 (Ill. 1988). For this case and subsequent cases discussed in this Comment, an in-depth description of the facts surrounding each is provided to (1) further highlight the frequency with which examples of the quandary addressed in this Comment arise and (2) offer a look into the reality of the situation each lawyer faced when confronting this "Catch-22" dilemma.

33 Id.

34 Id.

35 Id.

36 Id.

$37 \quad I d$. at 792.

38 Id. at 793-94.

39 Id. at 794. 
turpitude, and that [Himmel] failed in his duty to report such misconduct to the Commission." 40

After finding that Himmel violated his duty to report, the court determined that Himmel should be publicly disciplined to uphold the purposes of the disciplinary process such as maintaining the integrity of the legal profession, protecting the administration of justice, and safeguarding the public. ${ }^{41}$ The court thus suspended Himmel from the practice of law for one year based on the "serious nature of [his] failure to report Casey, the resulting interference with the Commission's investigation of Casey, and [Himmel's] ill-advised choice to settle with Casey rather than report his misconduct." 42

As another example, in In re Condit, Attorney Lawrence Condit settled his client's claim alleging legal malpractice, conversion, embezzlement, fraud, and conflict of interest against the client's former attorney, Eldridge. ${ }^{43}$ Upon Eldridge's breach of the settlement agreement, Condit and his client brought suit against Eldridge, and Eldridge's lawyers then responded by filing a bar complaint against Condit for violating the state's mandatory reporting requirement when he failed to report Eldridge's misconduct. ${ }^{44}$ Subsequently, Condit and the State Bar entered into a discipline by consent agreement under which Condit admitted to violating state mandatory reporting requirements and agreed to be publicly censured and to pay for all of the State Bar's litigation costs and expenses. ${ }^{45}$ However, the state disciplinary commission rejected the agreement and remanded the case to the State Bar for the filing of a complaint against Condit. ${ }^{46}$

Both Condit and the State Bar then appealed to the Arizona Supreme Court, certifying the question of whether the state ethical rule regarding the confidentiality of information relating to the representation of a client preempted Condit's duty to report Eldridge's professional misconduct under state mandatory reporting requirements. ${ }^{47}$ Declining to entirely handle the issue and set straight the existing interplay between the confidentiality and reporting ethical rules, the court nonetheless determined that when Condit

40 Id. at 793-95. The court made this finding over Himmel's arguments that he did not report Casey's conduct because he was respecting his client's wishes (and not motivated by his own financial gain) and Forsberg had approved/accepted his actions.

41 Id. at 795.

42 Id. at 796.

43 In re Condit, No. SB-94-0021-D, 1995 Ariz. Unpub. LEXIS 5, *1-2 (Mar. 14, 1995). The parties' negotiated settlement included in its terms a confidentiality agreement.

$44 I d$. at $* 2$.

$45 \quad$ Id. at $* 1-2$.

$46 I d$. at $* 2$. The commission's primary concern arose out of the confidentiality term included in the settlement agreement between Condit's client and Eldridge.

$47 \quad I d$. at $* 3$. 
brought suit "against Eldridge, the alleged acts of misconduct became a matter of public record." 48 Thus, the court explained that once Condit filed the lawsuit, there was nothing left to be kept confidential, and he was therefore unprotected from his failure to report Eldridge by the state client confidentiality ethical rule. ${ }^{49}$ As such, after weighing considerations including, inter alia, the conduct in the case occurring several years before In re Himmel was decided and the avoidance of further delay in finalizing the matter, the court ultimately approved of Condit's discipline by consent agreement and public censure for violating state mandatory reporting requirements. ${ }^{50}$

Ultimately, however, notwithstanding the possible consequences (such as affirmative discipline or public reprimand) of failing to report misconduct under mandatory reporting rules of professional conduct, "[a]ccountability within the legal profession through self-regulation is a crucial component of its autonomy, internal integrity, and reputation among the ... public. The duty to self-regulate contains elements of both furthering the public's interest in trustworthy guardians of the law, as well as protecting the integrity of the legal profession." 51 Thus, even if an attorney is licensed in a jurisdiction that less readily disciplines lawyers for failing to report professional misconduct, the "ends" the duty to report is aimed at achieving - "maintain[ing] the integrity of the legal profession, further[ing] the ends of justice, and protect[ing] the public from unscrupulous attorneys"-should be achieved regardless of the probability of discipline or a given state's proclivity to discipline lawyers. ${ }^{52}$

\section{Florida Retaliatory or Wrongful Discharge Law}

Florida has long been recognized as an at-will employment state..$^{53}$ This means that in Florida, "where the term of employment is discretionary with either party or indefinite, then either party for any reason may terminate it at any time and no action may be maintained for breach of the employment

$48 \quad I d$. at $* 4$.

49 Id.

$50 \quad I d$. at $* 5$.

51 Nikki A. Ott \& Heather F. Newton, Current Development 2002-2003: A Current Look at Model Rule 8.3: How is it Used and What are Courts Doing About it?, 16 GEO. J. LEGAL ETHICS 747, 758 (2003).

52 Skolnick v. Altheimer \& Gray, 730 N.E.2d 4, 13 (Ill. 2000).

53 See Smith v. Piezo Tech. and Prof'l Adm'rs, 427 So. 2d 182, 184 (Fla. 1983); DeMarco v. Publix Super Mkts., Inc., 384 So. 2d 1253, 1254 (Fla. 1980) (affirming and adopting reasoning of DeMarco v. Publix Super Mkts., 360 So. 2d 134, 136 (Fla. Dist. Ct. App. 1978); Wynne v. Ludman Corp., 79 So. 2d 690, 691 (Fla. 1955); Kimberly A. McCoy, Litigating Under the Florida Private Sector WhistleBlower's Act: Plaintiff Protection and Good Faith, 52 U. MiAMI L. REV. 855, 859 (1998). 
contract." ${ }^{54}$ In Hartley v. Ocean Reef Club, Inc., the Third District Court of Appeal of Florida considered a claim for retaliatory discharge of an at-will employee where the discharge on the part of the employer contravened the public's policy interests. ${ }^{55}$ In its analysis of determining "what constitutes public policy, or which of competing public policies should be given precedence," the court exercised judicial restraint and deferred the determination to the legislature. ${ }^{56}$ As such, the court concluded "that a significant change in the law such as the creation of a cause of action for retaliatory or wrongful discharge in this state is best left to the legislature." ${ }^{57}$ Therefore, the court held that "a common law cause of action for retaliatory or wrongful discharge does not exist in Florida." 58

In 1991, however, the Florida Legislature passed Sections 448.101-.105 of the Florida Statutes (commonly referred to as Florida's Private Sector Whistleblower Act) to protect whistleblowing private sector employees from employer retaliation. ${ }^{59}$ Section 448.102 prohibits private employers from "tak[ing] any retaliatory personnel action against an employee because the employee has" done one of the following:

(1) Disclosed, or threatened to disclose, to any appropriate governmental agency, under oath, in writing, an activity,

54 DeMarco, 360 So. $2 \mathrm{~d}$ at 136 (aff'd per curiam, DeMarco, 384 So. $2 \mathrm{~d}$ at 1254); see also Hartley v. Ocean Reef Club, Inc., 476 So. 2d 1327, 1330 (Fla. Dist. Ct. App. 1985) ("The established rule in Florida is that when the term of employment is discretionary or indefinite, either party may terminate the employment at any time for any reason or no reason without assuming any liability.").

55 Hartley, 476 So. 2d at 1328 (The employee was fired after "refus[ing] to build or order his workers to construct or plan any facilities without proper government approval."). This section focuses on Hartley because the public policy concern at issue in Hartley is comparable to the public's policy interest in ensuring the integrity and trustworthiness of the legal profession via a mandatory reporting requirement. See Alex B. Long, Retaliatory Discharge and the Ethical Rules Governing Attorneys, 79 U. COLO. L. ReV. 1043, 1063 (2008) ("[T]he public unquestionably has a substantial interest in insuring that attorneys comply with both the letter and spirit of the ethical rules governing attorneys. ... [T] $]$ he very existence and enforcement of such rules contributes to public confidence in the judicial process.").

56 Hartley, 476 So. $2 \mathrm{~d}$ at 1329

57 Id. The court reached this conclusion after acknowledging various jurisdictions' approval of the tort cause of action of retaliatory discharge in contravention of public policy. See id. at 1328-29.

58 Id. at 1330 (emphasis added); see also Smith v. Piezo Tech. and Prof'1 Adm'rs, 427 So. 2d 182, 184 (Fla. 1983) ("Some jurisdictions have recognized exceptions to [the employment at-will] rule and one exception takes the form of a common law tort for retaliatory discharge. Florida has not followed that path.”).

59 See Richard D. Tuschman, III, Another Look at the Notice Requirement of the Florida Private Sector Whistleblower's Act, 71 FLA. B. J. 10, 43 (1997) ("The Florida private sector Whistleblower's Act ... prohibits employers from taking an adverse employment action against an employee because the employee has disclosed, threatened to disclose, objected to, or refused to participate in a violation of law.”); McCoy, supra note 53, at 860; cf. Burden v. City of Opa Locka, No. 11-22018, 2012 U.S. Dist. LEXIS 144903, at *26 (S.D. Fla. Oct. 7, 2012) (“Florida's [public sector] Whistle-blower's Act was enacted with the intent to prevent retaliatory action against employees and persons who disclose government wrongdoing to the appropriate officials.”) (citing WHISTLEBLOWER's ACT, FLA. STAT. § 112.3187(2) (2017)). 
policy or practice of the employer that is in violation of a law, rule, or regulation; (2) Provided information to, or testified before, any appropriate governmental agency, person, or entity conducting an investigation, hearing, or inquiry into an alleged violation of a law, rule, or regulation by the employer; or (3) Objected to, or refused to participate in, any activity, policy, or practice of the employer which is in violation of a law, rule, or regulation. ${ }^{60}$

As a result, Section 448.102 seems to provide an express protection and remedy for lawyers who have been retaliated against by their employing law firms for reporting or threatening to report the professional misconduct of other lawyers. However, as discussed further in Part III below, the Florida Second District Court of Appeal in Snow v. Ruden, McClosky et al. has narrowly interpreted the meaning of the word "rule" under the Definitions section of the statute and deferred to the legislature to resolve the ironic paradox existing between Rule 4-8.3(a) and the lack of protection from employer retaliation for lawyers who adhere to their reporting obligation. ${ }^{61}$

\section{Florida At-Will Employment Contract Law and the Implied Covenant of Good Faith and Fair Dealing}

Under Florida contract law, the implied covenant of good faith and fair dealing is built into every contract. ${ }^{62}$ The covenant arises out of the implied understanding that under a contractual agreement, each party mutually promises to perform its obligations in good faith while expecting the other party to similarly perform. ${ }^{63}$ As such, the covenant functions to ensure that the contracting parties' reasonable commercial expectations are protected in light of their agreement. ${ }^{64}$

60 Florida Private SeCtOr WhistLeblower’s ACT, Fla. STAT. § 448.102 (2017). Subsection (1) of Section 448.102 applies only when "the employee has, in writing, brought the activity, policy, or practice to the attention of a supervisor or the employer and has afforded the employer a reasonable opportunity to correct the activity, policy, or practice."

61 See Snow v. Ruden, McClosky, Smith, Schuster \& Russell, P.A., 896 So. 2d 787 (Fla. Dist. Ct. App. 2005)

62 See, e.g., Cty. of Brevard v. Miorelli Eng'g, Inc., 703 So. 2d 1049, 1050 (Fla. 1997) ("Virtually every contract contains implied covenants and conditions. For example, every contract includes an implied covenant that the parties will perform in good faith.") (quoting Champagne-Webber, Inc. v. City of Fort Lauderdale, 519 So. 2d 696, 697 (Fla. Dist. Ct. App. 1988); Ins. Concepts and Design, Inc. v. Healthplan Servs., Inc., 785 So. 2d 1232, 1234 (Fla. Dist. Ct. App. 2001); Burger King Corp. v. Weaver, 169 F.3d 1310, 1315 (11th Cir. 1999).

63 See Cox v. CSX Intermodal Inc., 732 So. 2d 1092, 1097 (Fla. Dist. Ct. App. 1999) (quoting First Nationwide Bank v. Fla. Software Servs., Inc., 770 F. Supp. 1537, 1543 (M.D. Fla. 1991)).

64 See, e.g., Meruelo v. Mark Andrew of the Palm Beaches, Ltd., 12 So. 3d 247, 251 (Fla. Dist. Ct. App. 2009); Ins. Concepts and Design, Inc., 785 So. 2d at 1234; Cox, 732 So. 2d at 1097. 
However, beyond acknowledging that the implied covenant of good faith and fair dealing exists in every contractual relationship, Florida courts consistently adhere to restricting the reach of the implied covenant. ${ }^{65}$ For example, Florida courts maintain that the implied covenant of good faith and fair dealing should not be invoked to vary or override the express terms of a contract. ${ }^{66}$ Additionally, as discussed further in Part III below, a cause of action for breach of the implied covenant of good faith and fair dealing cannot be maintained under Florida contract law unless an express term of the contract has been breached. ${ }^{67}$

\section{A LACK OF PROTECTION FROM EMPLOYER RETAliation}

Given that Rule 4-8.3(a) of the Florida Rules of Professional Conduct imposes such a strict, mandatory reporting requirement, it would seem to follow that the law would protect lawyers who are retaliated against by their employing law firms when they uphold their ethical duties to report misconduct under mandatory reporting rules of professional conduct. However, as the following examples illustrate, that is not always the case.

In Snow v. Ruden, McClosky, Smith, Schuster \& Russell, P.A., Plaintiff Ann E. Snow appealed the dismissal of her two-count second amended complaint against her former law firm. ${ }^{68}$ She alleged (1) "a violation of section 448.101(2)-(3), Florida Statutes (1999)," and (2) "that her termination of employment was a breach of the implied covenant of good faith in her at-will employment contract as well as a violation of public policy." ${ }^{69}$ Snow, a member of the Florida Bar, had been hired as an associate by the law firm Ruden, McClosky when she discovered that her supervisor had improperly diverted fees to himself that were owed to the law firm. ${ }^{70}$ Snow's claim was that as an attorney licensed in Florida she was ethically

65 See, e.g., Burger King Corp., 169 F.3d at 1316 ("The Florida District Courts of Appeal have held unequivocally that the rights conferred by the implied covenant of good faith and fair dealing are limited."); Snow, 896 So. 2d at 791; Ins. Concepts and Design, Inc., 785 So. 2d at 1234.

66 See, e.g., Flagship Resort Dev. Corp. v. Interval Int'l, Inc., 28 So. 3d 915, 924 (Fla. Dist. Ct. App. 2010); Ins. Concepts and Design, Inc., 785 So. 2d at 1234; Cox, 732 So. 2d at 1098.

67 Ins. Concepts and Design, Inc., 785 So. 2d at 1234; Burger King Corp., 169 F.3d at 1316; Hospital Corp. of America v. Fla. Med. Ctr., Inc., 710 So. 2d 573, 575 (Fla. Dist. Ct. App. 1998). The Fifth District Court of Appeal of Florida has even gone to the extent of stating that a breach of the implied covenant is not recognized in Florida where the plaintiff alleges a wrongful dismissal. Kelly v. Gill, 544 So. 2d 1162, 1164 (Fla. Dist. Ct. App. 1989).

68 Snow, 896 So. $2 \mathrm{~d}$ at 789.

69 Id.

70 Id. at 789-90. 
required to report this illegal conduct under Rule 4-8.3 of the Florida Rules of Professional Conduct. ${ }^{71}$

In terms of Snow's claim under the Florida Private Sector Whistleblower Act, the Second District Court of Appeal of Florida focused on the language "law, rule, or regulation" in Section 448.102(1) as defined in Section 448.101(4). ${ }^{72}$ Based on the definition of this language in the statute, the court found that the rules governing the conduct of members of the Florida Bar, despite being designated as "rules," are not laws, rules, or regulations under Section 448.101(4) because they "do not flow from either a legislatively enacted statute, ordinance, or administrative rule. Neither do they originate from any similar federal source. Rather, [they] are promulgated by the Florida Supreme Court, the head of the judicial branch of state government, under . . . authority given . . by . . . the Florida Constitution." 73

Even after making this finding, the court still went on to recognize that the firm's reaction "may have been inappropriate." ${ }^{\text {" N4 }}$ Nonetheless, the court refrained from deciding the case on any grounds other than the language contained in the Definitions section of the statute and its interpretation. ${ }^{75}$ However, the court did acknowledge the quandary it was dealing with and evidently made it a point to mention that " $[\mathrm{w}]$ hether it is appropriate to afford whistle-blower protection to an attorney in Ms. Snow's circumstance is a policy-making function left to the legislature."76

The court also imposed a restricted reach (as discussed in Part II above) on the implied covenant of good faith built into Snow's at-will employment contract: "[t]here can be no cause of action for a breach of the implied covenant 'absent an allegation that an express term of the contract has been breached.""77 "[T] plaintiff can establish a term of the contract the other party was obligated to perform and did not." 78

Similar situations to that which took place in Snow have also occurred in other jurisdictions. In Jacobson v. Knepper \& Moga, P.C., shortly after

71 Id.

72 Id. at 791.

73 Id.

74 Id.

75 Id.

76 Id.

77 Id. at 791-92 (quoting Ins. Concepts \& Design, Inc. v. Healthplan Servs., Inc., 785 So. 2d 1232, 1234 (Fla. Dist. Ct. App. 2001).

78 Snow, 896 So. 2d at 792. After stating this point the court then cited a case from the United States Court of Appeals for the Eighth Circuit not in conformity with its construction of the implied covenant of good faith in Snow: Scott v. County of Ramsey, 180 F.3d 913, 918 (8th Cir. 1999) ("affirming the giving of a jury instruction stating that employment decisions or actions can be made for 'a good reason, bad reason or no reason at all, but they cannot be based on intentional retaliation"'). 
Plaintiff Alan P. Jacobson was hired as an associate with the law firm of Knepper \& Moga, P.C., he learned that the firm had been improperly filing consumer debt collection actions. ${ }^{79}$ After bringing the filing practice issue to the attention of Knepper, a principal partner at the firm, Knepper advised Jacobson that the matter would be corrected. ${ }^{80}$ However, Jacobson would subsequently realize on two separate occasions that the firm had not ceased its improper filing practices at all. ${ }^{81}$ In fact, after approaching Knepper with his concerns for a second time, Jacobson was again informed that the issue would be rectified. ${ }^{82}$ And after raising the issue with Knepper for a third time, Jacobson was terminated about two weeks later. ${ }^{83}$ As such, Jacobson brought suit against the firm "alleging that he had been wrongfully discharged in retaliation for reporting the firm's illegal practices to a principal partner of the firm." $" 84$

After initially denying the firm's motion to dismiss, the circuit court certified the following question to the appellate court: whether an Illinois attorney is prevented "from maintaining a cause of action for the Tort of Retaliatory Discharge against his non-client law firm employer due to the pre-eminence of the Rules of Professional Conduct?" 85 Reversing the appellate court's holding that Jacobson "was not precluded from maintaining an action for retaliatory discharge against his employing firm," the Illinois Supreme Court first recognized the "limited and narrow" scope of retaliatory discharge "as an exception to the general rule of at-will employment." ${ }^{\prime \prime 6}$ The court further described retaliatory discharge as an "action which seeks to achieve a proper balance among the employer's interest in operating a business efficiently and profitably, the employee's interest in earning a livelihood, and society's interest in seeing its public policies carried out." As such, for a plaintiff to maintain a retaliatory discharge action, he "must demonstrate that (1) he was discharged in retaliation for his activities; and (2) the discharge is in contravention of a clearly mandated public policy." $" 88$ Recognizing the lack of an exact definition of "clearly mandated public policy," the court noted that its case law allows retaliatory discharge actions where (1) employees are terminated in response to the filing (or anticipated

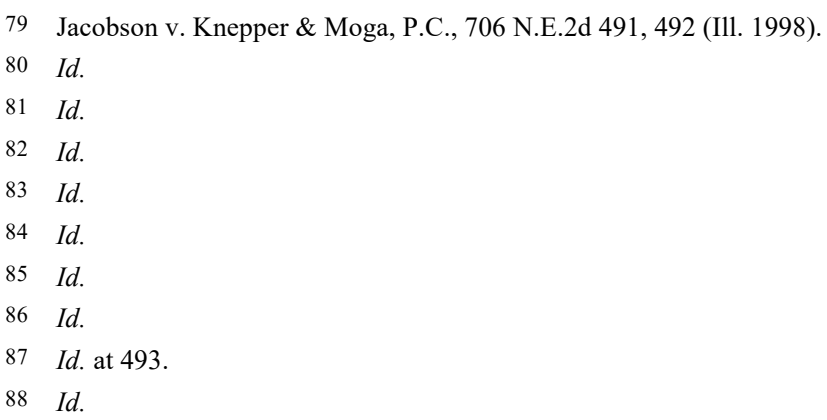


filing) of Workers' Compensation Act claims or (2) employees are terminated "in retaliation for the reporting of illegal or improper conduct," or "whistle blowing." 89

Turning its attention to the case before it, the court determined that the public policy safeguarded by the collection statutes, "that of protecting the debtor defendants' property and ensuring them due process, is adequately safeguarded without extending the tort of retaliatory discharge to employee attorneys." ${ }^{~}$ This is because licensed attorneys have professional and ethical obligations to report attorney misconduct, which ensures that the public policy under the collection statutes (that of protecting debtor defendants' property and ensuring due process) will be adequately safeguarded since attorneys with knowledge of improper violations of the statutes are required to report them. ${ }^{91}$ Thus, before reversing the appellate court's holding and circuit court's order denying the motion to dismiss, the court answered the certified question in the affirmative and found that "an attorney licensed to practice in the State of Illinois is prevented from maintaining a cause of action for the tort of retaliatory discharge against his nonclient law firm employer due to the preeminence of the Rules of Professional Conduct." ${ }^{\text {"92 }}$ At the same time, the dissent captured the essence of the dilemma surrounding the court's opinion:

Thus, one class of employees in this state, attorneys, has been stripped of a remedy which Illinois clearly affords to all other employees in such "whistle-blowing" situations. Today's opinion serves as yet another reminder to the attorneys in this state that, in certain circumstances, it is economically more advantageous to keep quiet than to follow the dictates of the Rules of Professional Responsibility. ${ }^{93}$

The Texas Supreme Court also confronted a slightly distinct, yet comparable situation to the situations presented in Snow and Jacobson. In Bohatch v. Butler \& Binion, after becoming a partner with the law firm of Butler \& Binion, Attorney Colette Bohatch was given access to internal firm billing reports. ${ }^{94}$ Based on her review of the reports, Bohatch grew suspicious that the office managing partner was overbilling for his time worked and

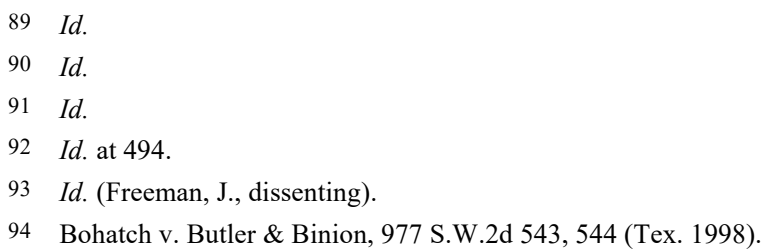


decided to raise the issue with another partner at the firm. ${ }^{95}$ Following the firm's investigation, Bohatch was informed that her contentions had no basis and that she should begin seeking other employment. ${ }^{96}$ Eventually, the firm gave Bohatch notice to vacate her office, Bohatch initiated an action against the firm, and Bohatch was expelled from the partnership. ${ }^{97}$

After a jury trial on Bohatch's claims for breach of fiduciary duty and breach of the duty of good faith and fair dealing, "the court [of appeals] concluded that Bohatch could not recover for breach of fiduciary duty" because "the firm's only duty to Bohatch was not to expel her in bad faith." 98 Subsequently, the Texas Supreme Court set out to consider "whether the fiduciary relationship between and among partners creates an exception to the at-will nature of partnerships; that is, in this case, whether it gives rise to a duty not to expel a partner who reports suspected overbilling by another partner." 99

Although recognizing the force behind Bohatch's position that "permitting a law firm to retaliate against a partner who in good faith reports suspected overbilling would discourage compliance with rules of professional conduct and thereby hurt clients," the court nonetheless rejected Bohatch's arguments in favor of maintaining the at-will nature of partnerships and the importance of "personal confidence and trust" among partners in a partnership (that may cease to exist in instances where partners accuse other partners of overbilling, for example). ${ }^{100}$ At the same time, however, the court emphasized that "[its] refusal to create an exception to the at-will nature of partnerships in no way obviate[d] the ethical duties of lawyers," noting the reality of dilemmas sometimes created by professional ethical duties (such as situations involving a partner's knowledge of another partner's overbilling practices). ${ }^{101}$

98 Id. ("The court of appeals stated that 'bad faith' in this context means only that partners cannot expel another partner for self-gain" and found no evidence in the present case that Bohatch was expelled for self-gain.).

$99 I d$.

$100 \quad I d$. at 546.

101 Id. at 547. 


\section{Potential Solutions to the LaCk OF Protection from EMPLOYER RETALIATION}

\section{A. Other Jurisdictions' Judicial Solutions}

On the other hand, various jurisdictions have responded more favorably to this issue. For example, in Wieder v. Skala, as a member of the New York State Bar, Plaintiff Wieder sued his former employing law firm for wrongfully discharging him as an associate "because of his insistence that the firm comply with the governing disciplinary rules by reporting professional misconduct allegedly committed by another associate."102 The issue presented before the Court of Appeals of New York was "whether plaintiff ha[d] stated a claim for relief either for breach of contract or for the tort of wrongful discharge in violation of [New York's] public policy."103 Wieder asserted that he had been wrongfully discharged because "of his insistence that L.L.'s [(a fellow associate in the firm $)$ ] misconduct be reported as required by DR 1-103 (A)."104

After reviewing its employment-at-will jurisprudence, the court stated that "[a]ssociates are, to be sure, employees of the firm but they remain independent officers of the court responsible in a broader public sense for their professional obligations." 105 In fact, the court agreed with Wieder that whenever an attorney is hired

as an associate to practice law with a firm there is implied an understanding so fundamental to the relationship and essential to its purpose as to require no expression: that both the associate and the firm in conducting the practice will do so in accordance with the ethical standards of the profession. ${ }^{106}$

The court also recognized the particular importance of a mandatory reporting rule of professional conduct because of the unique nature of selfregulation in the legal profession. ${ }^{107}$ As such, "by insisting that plaintiff disregard DR 1-103 (A) defendants were not only making it impossible for plaintiff to fulfill his professional obligations but placing him in the position

102 Wieder v. Skala, 609 N.E.2d 105, 106 (N.Y. 1992).

103 Id.

104 Id. The language of DR 1-103 is parallel to that of Rule 4-8.3 of the Florida Rules of Professional Conduct.

105 Id. at 108.

106 Id.

107 Id. 
of having to choose between continued employment and his own potential suspension and disbarment." 108 The court summarized the inherent dilemma:

Defendants, a firm of lawyers, hired plaintiff to practice law and this objective was the only basis for the employment relationship. Intrinsic to this relationship, of course, was the unstated but essential compact that in conducting the firm's legal practice both plaintiff and the firm would do so in compliance with the prevailing rules of conduct and ethical standards of the profession. Insisting that as an associate in their employ plaintiff must act unethically and in violation of one of the primary professional rules amounted to nothing less than a frustration of the only legitimate purpose of the employment relationship. ${ }^{109}$

Thus, the court concluded that Wieder stated a "valid claim for breach of contract based on an implied-in-law obligation in his relationship with defendants." $" 110$

At the same time, however, while recognizing Wieder's persuasive arguments and compelling circumstances in the case, the court refrained from extending the tort of retaliatory discharge to the facts of the case to avoid significantly altering any employment relationships that the legislature would be better suited to handle. ${ }^{111}$

Several years later, the New York Court of Appeals' position in Wieder was confirmed and adopted by the United States District Court for the Eastern District of New York in Kelly v. Hunton \& Williams. In Kelly, Plaintiff Peter M. Kelly began working in the New York litigation department of H\&W in October 1990. ${ }^{112}$ Around April or May of 1991, Kelly began suspecting Scott Wolas, a partner/rainmaker of the firm under whom he worked, of billing fraud. ${ }^{113}$ Around June of 1992, Kelly told Mason, another partner at the firm who, unbeknownst to Kelly, had been investing heavily through Wolas, about Wolas's improper billing of hours not actually worked. ${ }^{114}$ In response, Mason told Kelly "that things are not always what they seem, and that Wolas's

108 Id. at 109

109 Id. at $109-10$.

110 Id. at 110

111 Id.

112 Kelly v. Hunton \& Williams, No. 97-CV-5631 (JG)., 1999 WL 408416, at *1 (E.D.N.Y. June 17, 1999). After his first year with the firm, Kelly received considerably favorable first-year performance reviews along with the maximum pay raise for his class. The only major concession with his performance ratings appeared to be his not having passed the bar examination yet.

$113 I d$. at *2. Wolas had billed for hours that he did not actually work and had also improperly billed a number of fictitious hours on other specific instances.

114 Id. 
billing was not [Kelly's] concern."115 Additionally, although Kelly’s work and habits had not been substantially criticized before speaking with Mason, after the conversation Kelly began to be reprimanded for tardiness, work performance, failing to timely finalize his bar application, and billing fewer hours than the other New York litigation partners (including Wolas). ${ }^{116}$

Eventually, Kelly was asked to leave the firm and was given the option to either "(a) be fired immediately, without severance pay or a favorable job reference; or (b) announce his resignation and stay with the firm the next several months, which would gain him a favorable reference." ${ }^{\prime 17}$ Given this ultimatum, Kelly chose the coerced resignation because he had no other employment or source of income readily available, would have a difficult time obtaining another job without a favorable $\mathrm{H} \& \mathrm{~W}$ reference, and would have to disclose being fired on his bar application. ${ }^{118}$ During this time, H\&W conducted an internal investigation and "hearing" process regarding Wolas's billing practices. ${ }^{119}$ Ultimately finding that Wolas had not committed billing fraud, the firm also decided that its "determination that fraud had not been clearly established extinguished the obligation to report not only for the firm, but for the associates as well" (even in light of the New York Court of Appeals' decision in Wieder v. Skala). ${ }^{120}$

Several years after leaving $\mathrm{H} \& \mathrm{~W}$ and receiving various job references from the firm that were less than completely favorable, Kelly sued H\&W

alleging that [it] breached implied contractual obligations owed him when it terminated his employment with the firm. Specifically, [he claimed] that $\mathrm{H} \& \mathrm{~W}$ forced him to resign and implicitly threatened to withhold a favorable job reference, in order to impede and discourage him from reporting ... Wolas's billing fraud to the Disciplinary Committee. $^{121}$

In deciding H\&W's motion for summary judgment, the court recognized that Kelly was an at-will employee and that under New York law could be terminated at any time for any or no reason. ${ }^{122}$ However, Kelly's position was that his termination fell within the exception established in Wieder v. Skala, where the New York Court of Appeals held that an at-will associate can bring

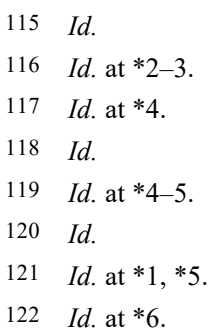


a cause of action "against his firm for breach of contract based on the firm's discharging him for his insistence that the firm comply with the Code of Professional Responsibility by reporting to the Disciplinary Committee the professional misconduct of another [lawyer]." "123 Over H\&W's argument that Wieder was inapplicable because Kelly had not yet passed the bar (and so was not subjected to attorney disciplinary rules), the court determined that the Wieder cause of action does extend to "unadmitted law graduates working as associates in law firms." 124 The court reasoned that "it would be anomalous to permit ... [unadmitted] associates to ignore unethical behavior that admitted associates are required to report" because of the close similarities between the functions, treatment, responsibilities, evaluation, and payment of unadmitted and admitted associates. ${ }^{125}$ Thus, the court rejected the notion that unadmitted associates cannot "face the dilemma of having to choose between continued employment at a firm and compliance with lawyers' disciplinary rules." ${ }^{126}$ As in Wieder, the court acknowledged (as applicable to unadmitted associates) the same ethical responsibilities and duties belonging to lawyers as members of the self-regulated legal profession and the "implied-in-law obligation[s]" firms owe to their lawyers. ${ }^{127}$

Lastly, the court further rejected H\&W's contentions that (1) an associate must report or threaten to report to the disciplinary committee as a prerequisite to avail himself of the Wieder cause of action, and (2) Wieder is inapplicable to situations where the only retaliation for reporting the associate would suffer is an unfavorable job reference (and not termination). ${ }^{128}$ First, the court explained that while an "associate's stated intention to go to the disciplinary authorities may be powerful circumstantial evidence of the firm's intent to punish and/or silence him ... it is neither dispositive nor necessary to the associate's claim." ${ }^{129}$ Second, the court stated that retaliation in the form of unfavorable job references "can effectively prevent" an associate from securing future employment, which thus places him in a situation comparable to the Wieder scenario "of having to choose between continued employment and the consequences of failing to comply with [mandatory reporting rules]." 130

Ultimately, the court's final sentence of the opinion before the denial of $\mathrm{H} \& W$ 's summary judgment motion recognizes the possibility that "a rational

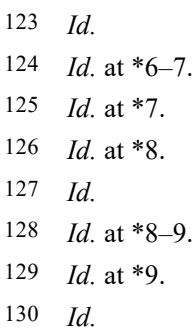


jury could conclude that $\mathrm{H} \& \mathrm{~W}$ fired plaintiff because he had insisted on airing Wolas's fraud, and implicitly conditioned its favorable references to prospective future employers on plaintiff's keeping quiet about that fraud." 131 This powerful statement captures the harsh realities facing associates when they are put in these "Catch-22" scenarios and must choose between the losing options of either (a) remaining quiet in the face of ethical misconduct and mandatory reporting requirements (while also risking disciplinary actions against them), or (b) reporting or threatening to report misconduct in the face of employment retaliation often without any available remedy because of their at-will employment status.

The Supreme Court of California in General Dynamics Corp. v. Superior Court also recognized a potential solution in the (slightly distinct, yet comparable) scenario involving the termination of in-house counsel. After working for General Dynamics Corporation for fourteen years, climbing the company's organizational ladder, and being considered for the positions of division vice-president and general counsel, Attorney Andrew Rose was terminated "abruptly and wrongfully." 132 In support of its decision to terminate Rose, General Dynamics' position was that (1) Rose's discharge was based on the company's loss of "confidence in Rose's ability to represent vigorously its interests" and (2) "Rose was subject to discharge at any time, "for any reason or for no reason," because of his employment as an in-house attorney. ${ }^{133}$ As a result, Rose initiated an action against General Dynamics alleging (1) "that he was subject to discharge only for 'good cause" based on General Dynamics' conduct and other assurances, and (2) that General Dynamics' stated reasons for his termination were mere pretext with the company's actual reasons stemming from a retaliatory motive against Rose. ${ }^{134}$

As such, after the court of appeal's ruling that "the complaint was sufficient to survive a general demurrer as to both theories of relief," the supreme court granted review to consider "whether an attorney's status as an employee bars the pursuit of implied-in-fact contract and retaliatory

131 Id. at $* 10-11$.

132 General Dynamics Corp. v. Superior Court., 876 P.2d 487, 490 (Cal. 1994).

133 Id. at $490-91$

134 Id. Rose's complaint alleged:

[T] he "real" reasons motivating his firing had more to do with an attempt by company officials to cover up widespread drug use among the General Dynamics workforce, a refusal to investigate the mysterious "bugging" of the office of the company's chief of security, and the displeasure of company officials over certain legal advice Rose had given them, rather than any loss of confidence in his legal ability or commitment to the company's interests. 
discharge tort causes of action against the employer that are commonly the subject of suits by non-attorney employees who assert the same claims." ${ }^{, 135}$

First, the court concluded that in-house attorneys are permitted to pursue "just cause" contractual claims in the same way as nonattorney employees because these contract claims "are unlikely to implicate values central to the attorney-client relationship." 136 In terms of retaliatory discharge, the court first recognized that this cause of action arises out of employers' implied-inlaw duty "to conduct [their] affairs in compliance with public policy."137 Furthermore, the court acknowledged that the tort functions primarily to serve the public's policy interests as opposed to the interests of any particular plaintiff-employee. ${ }^{138}$ Given these overarching principles, the court thus noted that when a plaintiff maintains a cause of action for retaliatory discharge, he is provided a remedy for (1) the direct purpose of being compensated for his loss of employment. and (2) the indirect purpose of "vindicating the underlying fundamental public policy itself.", 139

The court then turned its attention to analyzing the dual allegiance attorneys serve as a class of professionals. ${ }^{140}$ "On the one hand, an attorney's highest duty is to the welfare and interests of the client. This obligation is channeled, however, by a limiting and specifically professional qualification: ... [being] bound at all events not to transgress ... ethical norms that distinguish their work from that of the nonattorney." ${ }^{141}$ Given the competing forces surrounding this "duality of allegiance," the court observed the possibility that situations may arise where an attorney is placed in "a genuine moral dilemma." 142 For example, in addition to the situations faced by outside counsel employed by law firms - who actually "enjoy a measure of professional distance and economic independence that usually serves to lessen the pressure to bend or ignore professional norms"-in-house counsel are especially susceptible to client/ethical dilemmas because of their employment by profit-maximization focused corporations and their "virtually complete dependence on the good will and confidence of a single employer to provide livelihood and career success." considerations in hand with the fact that attorneys" "professional work is by definition affected with a public interest," the court concluded that "in-house

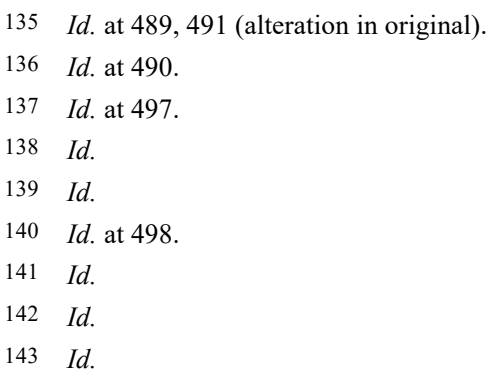


counsel, forced to choose between the demands of the employer and the requirements of a professional code of ethics have, if anything, an even more powerful claim to judicial protection than their nonprofessional colleagues." 144

The court also acknowledged the decisions of other courts that have concluded that in-house counsel are prevented from bringing retaliatory discharge actions before refusing to adopt their rationales. ${ }^{145}$ In those cases, the courts' reasoning was two-fold: first finding that permitting retaliatory discharge actions by in-house counsel could only harm clients' overall confidences in the confidential nature of matters communicated in the attorney-client relationship, and secondly finding that allowing such actions, which are based on serving fundamental public policy underpinnings, was redundant since attorneys already have mandatory ethical duties to safeguard the public's policy interests, which therefore alleviates the need for any tort remedy to persuade or encourage the attorney to protect such interests. ${ }^{146}$ With these ideas in mind, the California Supreme Court explained that they actually weigh in favor of permitting retaliatory discharge actions where an employee is terminated for adhering to or refusing to violate ethical duties:

Granted the priest-like license to receive the most intimate and damning disclosures of the client, granted the sanctity of the professional privilege, granted the uniquely influential position attorneys occupy in our society, it is precisely because of that role that attorneys should be accorded a retaliatory discharge remedy in those instances in which mandatory ethical norms embodied in the Rules of Professional Conduct collide with illegitimate demands of the employer and the attorney insists on adhering to his or her clear professional duty. It is, after all, the office of the retaliatory discharge tort to vindicate fundamental public policies by encouraging employees to act in ways that advance them. By providing the employee with a remedy in tort damages for resisting socially damaging organizational conduct, the courts mitigate the otherwise considerable

$144 I d$. (explaining that "it is virtually certain that, without the prospect of limited judicial access, in-house attorneys . . . confronted with the dilemma of choosing between adhering to professional ethical norms and surrendering to the employer's unethical demands will almost always find silence the better part of valor. Declining to provide a limited remedy under defined circumstances will thus almost certainly foster a degradation of in-house counsel's professional stature.") (alteration in original).

145 Id. at $500-01$

146 Id. at 500. 
economic and cultural pressures on the individual employee to silently conform. ${ }^{147}$

As further support for its position, the court also pointed to several cases such as Parker v. $M \& T$ Chemicals, Inc. and Wieder v. Skala that have likewise identified "the importance of professional ethical codes as a counterweight to employer overreaching." 48 Lastly, before affirming the court of appeal's judgment and remanding the case for further proceedings, the court explained the qualified and limited nature of its holding and the practicalities surrounding it:

In addition to retaliatory discharge claims founded on allegations that an in-house attorney was terminated for refusing to violate a mandatory ethical duty embodied in the Rules of Professional Conduct, judicial access ought logically extend to those limited circumstances in which inhouse counsel's nonattorney colleagues would be permitted to pursue a retaliatory discharge claim and governing professional rules or statutes expressly remove the requirement of attorney confidentiality. ${ }^{149}$

As a final example of the potential solutions reached by the courts on this issue, in Matzkin v. Delaney, Zemetis, Donahue, Durham \& Noonan, PC, Associate Attorney Bruce Matzkin was representing a client at trial "when he learned that his opposing counsel had telephoned two witnesses and told them that they did not have to testify in court, even though they had been subpoenaed." 150 While Matzkin intended to report his opposing counsel's conduct to the statewide grievance committee in accordance with mandatory ethical reporting requirements, multiple partners at his law firm cautioned him against initiating any grievance without the firm's approval. ${ }^{151}$ After finishing the matter against his opposing counsel and being expressly forbidden by his firm from filing a grievance in the firm's name, Matzkin told his firm that he would independently file a grievance and was subsequently terminated thereafter. ${ }^{152}$ As a result, Matzkin initiated a wrongful discharge action against his firm alleging that he was terminated to

\footnotetext{
$147 I d$. at 501 (alteration in original). 1989)).

148 Id. at 501-02 (citing Parker v. M \& T Chems., Inc., 566 A.2d 215 (N.J. Super. Ct. App. Div.

$149 I d$. at 502-05 (alteration in original).

150 Matzkin v. Delaney, Zemetis, Donahue, Durham \& Noonan, PC, No. CV0440002885, 2005 WL 2009277, at*1 (Conn. Super. Ct. July 29, 2005).

151 Id.

152 Id.
} 
be prevented from filing a grievance, and the firm responded by filing a motion to strike. ${ }^{153}$

In deciding the motion to strike, the court first recognized the inherent focus on public policy surrounding the wrongful discharge cause of action, which exists to provide a remedy in situations where an employee's "discharge involved impropriety derived from some important violation of public policy." 154 Accordingly, where a plaintiff employee claims he was wrongfully discharged, he must allege whether "his discharge violated any explicit statutory or constitutional provision ... or ... contravened any judicially conceived notion of public policy."155

Analyzing this requirement, the court determined that "the Rules of Professional Conduct are a judicially conceived public policy" and further supported its finding in the following ways: (1) citing a federal district court case from the District of Connecticut that concluded that the Connecticut Supreme Court would acknowledge a violation of the Rules of Professional Conduct as a "public policy violation ... sufficient to support a wrongful discharge cause of action;" 156 (2) noting that the Connecticut Supreme Court "has found clear statements of public policy in the Rules of Professional Conduct in other instances;" (3) citing the New York Court of Appeals' Wieder v. Skala decision; and (4) citing language in the preamble to the Rules of Professional Conduct indicating the Rules' concern for the public's policy interests. ${ }^{157}$ Along these lines, the court also rejected the firm's argument "that the preamble of the Rules ... explicitly states the rules are not intended to be a basis of civil liability" by explaining that while the firm's position accurately reflected the intent of the Rules, this does not necessarily bar the Rules from "embody[ing] a public policy of sufficient clarity or consequence to justify a claim for wrongful discharge against a lawyer's employer."158

Ultimately, the court held that given the self-regulated nature of the legal profession, "no lawyer's employment should be conditioned upon turning a blind eye to violations of the Rules which are applicable to all lawyers. To allow this would compromise the autonomy of the profession." 159 As such,

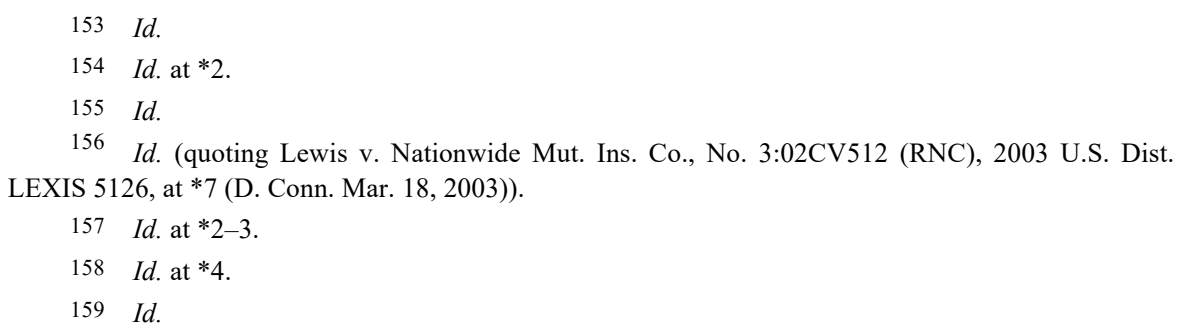


the court found that the Rules of Professional Conduct are an important public policy and denied the firm's motion to strike. ${ }^{160}$

\section{B. Analysis of Judicial Solutions and Discussion of Other Nonjudicial Solutions}

As set forth above, Snow v. Ruden, McClosky et al., Florida's at-will employment doctrine, and the silence of the Florida Rules of Professional Conduct currently exacerbate the existing tension between Rule 4-8.3(a)'s mandatory reporting requirement and the lack of protection from employer retaliation for lawyers who report or insist on reporting the misconduct of other lawyers. However, through the application of the potential judicial and nonjudicial solutions presented in this Comment, Florida lawyers will no longer be "left out in the cold" when confronted with the ironic paradox of reporting under Rule 4-8.3(a) and being retaliated against by law firm employers for adhering to the mandatory reporting rule without any protection.

First, like the courts in General Dynamics Corp. and Matzkin, Florida courts should similarly recognize a tort cause of action for retaliatory or wrongful discharge in contravention of public policy when an attorney is retaliated against for adhering to the mandatory obligations imposed by Rule 4-8.3(a). ${ }^{161}$ The Florida Rules of Professional Conduct undeniably "express clear and specific public policy."162 Rather than simply serving as "mere internal regulations of the profession," the Florida Rules exist to "define the minimal standards applicable to lawyers," which serve the public's interest in the overall integrity of the legal profession. ${ }^{163}$ As a result, the Florida Rules "embody a public policy of sufficient clarity or consequence to justify a claim for wrongful discharge against a lawyer's employer." 164 Accordingly, Florida courts-like the courts in other jurisdictions - should finally progress Florida's at-will employment doctrine towards recognizing the tort of retaliatory or wrongful discharge in situations where improper employer retaliation negatively impacts significant public policy concerns, such as the

$160 I d$. The court also agreed with the position that a plaintiff employee does not have to take action (such as actually reporting the misconduct) "to vindicate the important public policy." Id.

161 See also Kirik, supra note 5, at 408 ("Private law firm attorneys wrongfully discharged for refusing to violate their professional code of ethics should be allowed a cause of action for retaliatory discharge. Courts should recognize a 'public policy by professional code exception' to the at-will employment of an attorney-employee in private practice.").

$162 I d$. (referring to the ABA Model Rules of Professional Responsibility).

163 Id. at 409

164 Matzkin, 2005 WL 2009277, at *4. 
potential non-adherence to the mandatory reporting provision of the Florida Rules of Professional Conduct. ${ }^{165}$

Second, the Florida Legislature has ignored the conflict lingering before it: a law firm's unfettered ability to retaliate against at-will attorneys who adhere to Rule 4-8.3(a) jeopardizes attorney adherence to the Florida Rules of Professional Conduct and the public's confidence in the legal profession. ${ }^{166}$ As such, given the public's policy interest in lawyers' adherence to the Florida Rules of Professional Conduct, the Florida courts' unwillingness to recognize the common law cause of action for retaliatory or wrongful discharge, and the Snow court's direct call to the legislature to determine whether whistleblower protection should be afforded to attorneys like Plaintiff Snow, ${ }^{167}$ the Florida Legislature should step in to resolve this issue by redrafting the Definitions section of the Florida Private Sector Whistleblower Act to include the Florida Rules of Professional Conduct into the definition of "[1]aw, rule, or regulation."

The Snow court's holding provides the Florida Legislature with the perfect platform to amend the Florida Private Sector Whistleblower Act to resolve this issue. The legislature could declare that the Florida Rules of Professional Conduct - rules adopted by a co-equal branch of government (the Florida Supreme Court) acting pursuant to its constitutional authority to regulate the legal profession ${ }^{168}$ - are now included within the statute as protected "rules" for which attorney adherence cannot be retaliated against by employers without consequence. In this way, the legislature would resolve the existing conundrum that is the lack of protection from employer retaliation for following a mandatory rule of professional conduct.

Third, like the courts in Wieder and Kelly, Florida courts should allow at-will attorneys to sue for breach of the implied covenant of good faith and fair dealing when their law firm employers retaliate against them for adhering to Rule 4-8.3(a). As stated in Wieder, when a law firm hires an attorney to practice law, "there is implied an understanding so fundamental to the relationship and essential to its purpose as to require no expression: that both the associate and the firm in conducting the practice will do so in accordance with the ethical standards of the profession." "169 And as should further go without saying, the fundamental purpose surrounding the relationship

165 Kirik, supra note 5, at 409 ("To deny an attorney-employee of a private law firm a remedy for adhering to his professional ethics does not encourage respect for the law. It weeds out the honest attorneys.").

166 See Long, supra note 55, at 1065.

167 See Snow v. Ruden, McClosky, Smith, Schuster \& Russell, P.A., 896 So. 2d 787, 791 (Fla. Dist. Ct. App. 2005).

168 See Long, supra note 55, at 1082.

169 Wieder v. Skala, 609 N.E.2d 105, 108 (N.Y. 1992). 
between associate and law firm is non-waivable. Accordingly, the fact that Florida attorneys cannot waive their mandatory reporting obligation clearly contributes to the reality of being caught between adhering to Rule 4-8.3(a) and facing employer retaliation without a remedy.

Additionally, the restrictive holding in Snow (and other Florida cases) regarding the implied covenant of good faith and fair dealing is flawed. This restriction, that an express provision of the contract must be breached before the implied covenant applies, does not entirely make sense given that under such circumstances, the plaintiff's recovery will be based on the breach of the express provision itself, thus making the implied covenant superfluous. As such, to give actual force to the implied covenant, it needs to be applicable in situations like Snow where the ethical practice of law is inherently built into the at-will attorney's employment relationship with an employing law firm. ${ }^{170}$ Therefore, it appears to be axiomatic that Florida at-will attorneys should be able to sue for breach of the implied covenant of good faith and fair dealing when their law firm employers retaliate against them for adhering to Rule 4-8.3(a).

Fourth, the Florida Supreme Court should draft a new rule (or alternatively include as a provision or comment under Rule 4-8.4, Misconduct) in the Florida Rules of Professional Conduct proscribing employer retaliation against an at-will attorney who adheres to Rule 4$8.3\left(\right.$ a) ${ }^{171}$ The goal of the new rule or addition of a provision or comment under Rule 4-8.4 $4^{172}$ would be the deterrence of employer retaliation via the consequences of disciplinary action or suspension under the Florida Rules of Professional Conduct. ${ }^{173}$ Although this solution would not serve as an affirmative remedy for at-will attorneys retaliated against by their employing law firms, it would certainly resolve the Florida Rules of Professional Conduct's silence on the issue of employer retaliation against at-will attorneys. Furthermore, with an express statement built into the Florida Rules, it would seem to follow that the possibility of disciplinary action or suspension would deter law firms and employing attorneys from retaliating against an at-will attorney. As such, law firms would have to "think twice" before taking adverse employment action against an at-will attorney just because they can under the current state of the law.

170 See id

171 See Richmond, supra note 5, at 1850-51.

172 See id. at 1846 (explaining that the parallel misconduct rule under the Model Rules of Professional Responsibility, Rule 8.4, would be "broad enough to encompass conduct aimed at discouraging or punishing associates who intend to or who actually honor the [Model] Rule 8.3(a) reporting mandate.”).

173 See id. at 1851. 


\section{CONClusion}

The Preamble to the Florida Rules of Professional Conduct establishes lawyers as "officers of the court" and recognizes the self-governing nature of the legal profession. As such, in addition to requiring adherence to the rules, the Florida Rules of Professional Conduct also endow all lawyers with the responsibility of ensuring other lawyers' adherence to the rules. This charge of responsibility is directly stated in Rule 4-8.3(a), which explicitly requires "[a] lawyer who knows that another lawyer has committed a violation of the Rules of Professional Conduct that raises a substantial question as to that lawyer's honesty, trustworthiness, or fitness as a lawyer in other respects [to] inform the appropriate professional authority."

However, although Rule 4-8.3(a) requires lawyers to report such misconduct, the Rules fail to provide any express protection for lawyers who are retaliated against by employers because they report (or insist on reporting) the misconduct of other lawyers. Furthermore, Florida courts do not recognize the common law tort cause of action for retaliatory or wrongful discharge; the Second District Court of Appeal of Florida has also held that Florida lawyers are precluded from redress under Florida's Private Sector Whistleblower Act when they are retaliated against by an employer for adhering to (or insisting on adherence to) Florida's mandatory reporting requirement; and Florida courts will not find a breach of the contractual implied covenant of good faith and fair dealing (unless an express term of the at-will employment contract has been breached) in situations where at-will lawyers are similarly retaliated against.

As a result, for Rule 4-8.3(a) to have full force and reach its potential of being an affirmative vehicle for self-regulation of the legal profession, attorneys need to feel confident that they will have protection or a remedy if they face retaliatory employment consequences for adhering to the mandatory duty to report misconduct. However, given Florida's current stance on the issue, at-will attorneys are likely to find themselves hesitating before confidently following their duty to report misconduct under Rule 48.3(a). The result is an overall negative toll on the integrity of the legal profession. Accordingly, Florida courts should, "[i]n exercising their common law powers, ... not kneel in blind obedience to ... misguided reliance on precedent. [T] hey [should] seek in every case a just resolution, identifying those circumstances that lay claim to conscience, considered in light of applicable principles of law." 174

44 General Dynamics Corp. v. Superior Court, 876 P.2d 487, 494 (Cal. 1994) (alteration in 
[Vol. 13:1175

Thus, given these maxims and considering the tension between Rule 48.3(a)'s mandatory reporting requirement and the lack of protection from employer retaliation for lawyers who report or insist on reporting the misconduct of other lawyers, (1) Florida courts should recognize in such situations a tort cause of action for retaliatory or wrongful discharge in contravention of public policy, (2) the Florida Legislature should redraft the Definitions section of the Florida Private Sector Whistleblower Act to include the Florida Rules of Professional Conduct into the definition of "[1]aw, rule, or regulation," (3) Florida courts should allow claims for breach of the implied covenant of good faith and fair dealing with respect to at-will lawyers' employment contracts in such situations, or (4) the Florida Supreme Court should draft a new rule (or alternatively include as a provision or comment under Rule 4-8.4, Misconduct) in the Florida Rules of Professional Conduct proscribing such employer retaliation. 